\title{
Influence of winds on temporally varying short and long period gravity waves in the near shore regions of the eastern Arabian Sea
}

\author{
J. Glejin ${ }^{1}$, V. Sanil Kumar ${ }^{1}$, T. M. Balakrishnan Nair ${ }^{2}$, and J. Singh ${ }^{1}$ \\ ${ }^{1}$ Ocean Engineering, CSIR-National Institute of Oceanography (Council of Scientific \& Industrial Research), Dona Paula, \\ Goa 403004 India \\ ${ }^{2}$ Indian National Centre for Ocean Information System (Ministry of Earth Sciences), "Ocean Valley”, Pragathi Nagar (BO), \\ Nizampet (SO), Hyderabad 500090 India
}

Correspondence to: V. Sanil Kumar (sanil@nio.org)

Received: 24 July 2012 - Published in Ocean Sci. Discuss.: 25 September 2012

Revised: 24 February 2013 - Accepted: 6 March 2013 - Published: 20 March 2013

\begin{abstract}
Wave data collected off Ratnagiri, west coast of India, during 1 May 2010 to 30 April 2012 are used in this study. Seasonal and annual variations in wave data controlled by the local wind system such as sea breeze and land breeze, and remote wind generated long period waves are also studied. The role of sea breeze on the sea state during pre- and postmonsoon seasons is studied and it is found that the maximum wave height is observed at 15:00 UTC during the premonsoon season, with an estimated difference in time lag of $1-2 \mathrm{~h}$ in maximum wave height between premonsoon and postmonsoon seasons. Observed waves are classified in to (i) short waves $\left(T_{\mathrm{p}}<8 \mathrm{~s}\right)$, (ii) intermediate waves $\left(8<T_{\mathrm{p}}<13 \mathrm{~s}\right)$, and (iii) long waves $\left(T_{\mathrm{p}}>13 \mathrm{~s}\right)$ based on peak period $\left(T_{\mathrm{p}}\right)$ and the percentages of occurrence of each category are estimated. Long period waves are observed mainly during the pre- and the postmonsoon seasons. During the southwest monsoon period, the waves with period $>13 \mathrm{~s}$ are a minimum. An event during 2011 is identified as swells propagated from the Southern Ocean with an estimated travelling time of 5-6 days. The swells reaching the Arabian Sea from the south Indian Ocean and Southern Ocean, due to storms during the pre- and postmonsoon periods, modify the near surface winds due to higher phase wave celerity than the wind speed. Estimation of inverse wave age using large-scale winds such as NCEP (National Centers for Environmental Prediction) reflects the presence of cyclonic activity during pre- and postmonsoon seasons but not the effect of the local sea breeze/land breeze wind system.
\end{abstract}

\section{Introduction}

Waves are the dominant factor influencing the near shore processes. The dominant portion of the wave spectrum in terms of energy is associated with the surface waves ranging from 1 to $30 \mathrm{~s}$ (gravity waves). Two types of gravity waves in the ocean are (i) wind seas due to local wind, and (ii) swells generated elsewhere due to remote wind systems and propagating over large distances. The gravity waves along the west coast of India mainly depend on the wind conditions prevailing over the three different seasons; viz. southwest (SW) monsoon or summer monsoon (June-September), north east (NE) monsoon or postmonsoon (October-January), and premonsoon or fair weather period (February-May) (Glejin et al., 2012). In coastal regions, gulfs and bays, although mixed seas are frequently observed, there is a predominance of wind seas (Hwang et al., 2011). In open and large oceanic regions, usually there is a predominance of swell fields generated by remote storms. A proper estimation of the wind seas is needed to improve our theoretical understanding of wave growth and to validate wave models (Ardhuin et al., 2009; Donelan et al., 1985).

Wave climate of the Arabian Sea and that off the west coast of India is influenced by the monsoonal winds during the SW monsoon resulting in high wave activity. A relatively calm condition prevails during the rest of the year. The changes in wave characteristics along the west coast of India are virtually identical at locations spaced at $200 \mathrm{~km}$ (Kumar et al., 2012). Direction of wave approach is from the west and WSW during the SW monsoon, west and WNW during the 
NE monsoon and SW during fair weather periods (Kumar et al., 2006). Neetu et al. (2006) studied the impact of sea breeze on the diurnal cycle of the sea state off the Goa region along the central west coast of India during premonsoon season using 3-hourly wave data. Average wind speed during the $\mathrm{SW}$ monsoon is $9.7 \mathrm{~m} \mathrm{~s}^{-1}$ and reaches up to a maximum of $12.5-15.3 \mathrm{~m} \mathrm{~s}^{-1}$. During the post- and premonsoon seasons, the mean wind speed decreases to $5.6 \mathrm{~m} \mathrm{~s}^{-1}$ (Kumar et al., 2006). In premonsoon season, wind sea plays a major role in near shore wave climate (Rao and Baba, 1996). Kumar et al. (2010) studied the characteristics of swells and wave growth during the onset of summer monsoon. Dominance of swells along the west coast of India is observed during the SW monsoon (Glejin et al., 2012; Kumar et al., 2000, 2012). The studies mentioned above are based on the wave data measured for a particular season or short period during the Indian monsoon system.

When winds are blowing over the sea surface they transfer momentum from the atmosphere to the sea waves, forming wind generated waves. When long waves travel faster than the surface wind, momentum can be transferred from ocean wave to near surface air and is termed as the wave driven wind (Harris, 1966). Hanley et al. (2010) studied the coupling between wind and wave using inverse wave age. Hanley et al. (2010) also used the inverse wave age to identify the presence of swells in the tropics generated by the Southern Ocean storms. A general wave condition in the Arabian Sea during premonsoon and SW monsoon periods also depend on the swells and wind sea identified from the far northwest Arabian Sea because of the northwesterly Shamal winds (Aboobacker et al., 2011a; Glejin et al., 2013). Many authors reported the presence of SW swells (Kumar et al., 2000, 2009, 2012; Kurian et al., 2009) off the west coast of India, but their generating area remain unknown.

Hamilton (1992) studied the measured long period waves and low amplitude swells observed from wave buoys deployed in the western North Atlantic Ocean. Swell waves of long period are also identified and studied in the Pacific Ocean (Munk et al., 1963; Snodgrass et al., 1966) and Atlantic Ocean (Barber and Ursell, 1948). These fast moving swells arriving at calm or light wind conditions will have impacts on the ocean-atmosphere interface (Harris, 1966). The spatial and temporal structure of wave induced airflow is an important factor to the wind-wave coupling (Hristov et al., 2003). Beside the addition of energy to the atmosphere, swell also transfers energy to the ocean mixed layer (Ardhuin and Jenkins, 2006). So it is important to identify the originating locations of these long period swells, their propagation and seasonal variation in order to estimate the energy transfer at the ocean-atmosphere interface for selected domains and for wave model and forecast studies.

The present study analyzes and examines the seasonal variations of wind sea, and swell characteristics of gravity waves measured and calculated at a high temporal resolution of $30 \mathrm{~min}$ throughout the annual cycle. Inverse wave age is used to identify the presence of long period swells from the Southern Ocean during strong southwest monsoons and to assess air-sea momentum transfer regimes during different seasons with and without sea/land breeze systems. Seasonal and annual information about the effect of local wind systems, long period waves and sea states over the eastern Arabian Sea during a year is also examined. In this present study, we analyse the effect of long period swells over the oceanatmosphere interface using collected wave data. The results provide basic information for further study of the influence of waves on the mixed layer depth by transferring momentum between the ocean and the atmosphere.

\section{Data and methodology}

Wave data measured off Ratnagiri, eastern Arabian Sea (Fig. 1), during 1 May 2010 to 30 April 2012 using directional wave rider buoy (Barstow and Kollstad, 1991) is used in the study. The measurement location is off the central west coast of India at a water depth of $13 \mathrm{~m}\left(16^{\circ} 58^{\prime} 48^{\prime \prime} \mathrm{N}\right.$, $\left.73^{\circ} 15^{\prime} 30^{\prime \prime} \mathrm{E}\right)$. The data recorded continuously at $1.28 \mathrm{~Hz}$ and the data for every $30 \mathrm{~min}$ are processed as one record. Wave spectrum is obtained through Fast Fourier transform (FFT). FFT of 8 series, each consisting of 256 measured vertical elevations of the buoy data, are added to obtain the spectra. The high frequency cutoff is at $0.58 \mathrm{~Hz}$ and the resolution is $0.005 \mathrm{~Hz}$. Significant wave heights $\left(H_{m 0}\right)$ which equals $4 \sqrt{m_{0}}$ and mean wave period $\left(T_{m 02}\right)$ which equals $\sqrt{m_{0} / m_{2}}$ are obtained from the spectral moments. Here $m_{n}$ is the $n$-th order spectral moment and is given by

$m_{n}=\int_{0}^{\infty} f^{n} S(f) \mathrm{d} f, n=0$ and $2, S(f)$ is the spectral energy density at frequency $f$. The period corresponding to the maximum spectral energy, i.e., spectral peak period $\left(T_{\mathrm{p}}\right)$ is estimated from the wave spectrum. Peak wave direction $\left(D_{\mathrm{p}}\right)$ corresponding to the spectral peak is estimated based on circular moments (Kuik et al., 1988). Measurements are made in Coordinated Universal Time (UTC) and the time referred in the paper is in UTC. The local time is $05: 30 \mathrm{~h}$ ahead of UTC. Measured wave data for the period 1 May 2010 to 30 April 2011 is termed as data for 2010 and that during 1 May 2011 to 30 April 2012 is termed as data for 2011.

Wind seas and swells from the measured data are separated through the method described by Portilla et al. (2009). Portilla et al. (2009) proposed a 1-D separation algorithm on the basis of the assumption that the energy at peak frequency of a swell system cannot be higher than the value of a PM spectrum (Pierson and Moskowitz, 1964) with the same peak frequency. The algorithm calculates the ratio $\left(\gamma^{*}\right)$ between the peak energy of a wave system and the energy of a PM spectrum at the same frequency. If $\gamma^{*}$ is above a threshold value of 1 , the system is considered to represent wind sea, else it is taken to be swell and a cut off frequency $f_{\mathrm{c}}$ is estimated (Portilla et al., 2009). Swell parameters are computed by integrating frequencies ranging from $0.025 \mathrm{~Hz}$ to $f_{\mathrm{c}}$ and 


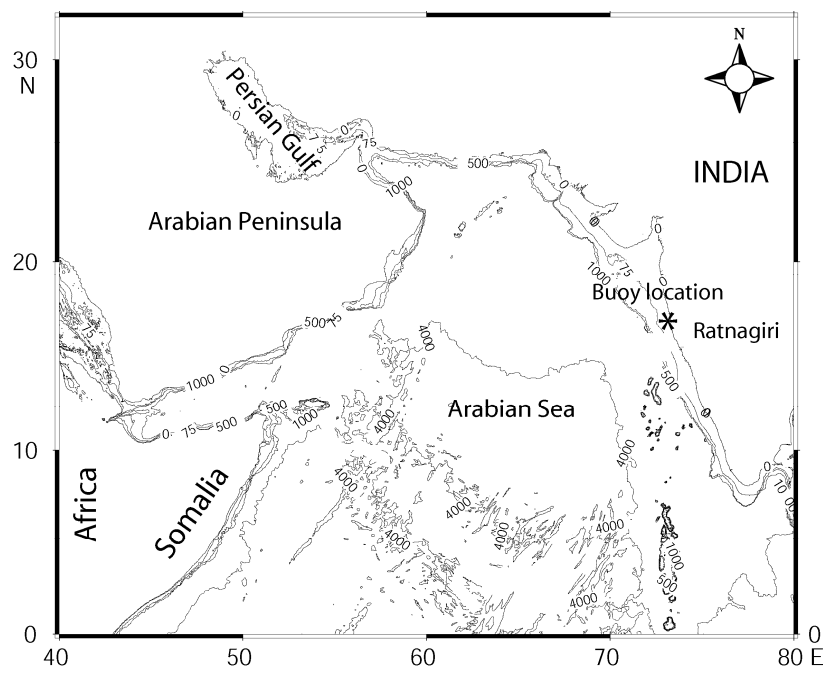

Fig. 1. Study area showing the wave measurement location. The depth contours are in meters.

wind sea parameters are computed by integrating frequencies ranging from $f_{\mathrm{c}}$ to $0.58 \mathrm{~Hz}$.

Reanalysis data of zonal and meridional components of wind speed at $10 \mathrm{~m}$ height at 6 hourly intervals from NCEP/NCAR (National Center for Atmospheric Research)(Kalnay et al., 1996) is used to identify the propagation of the Southern Ocean storm and the seasonal wind pattern over the western Indian Ocean. These data were provided by the NOAA-CIRES (Cooperative Institute for Research in the Environmental Sciences) Climate Diagnostics Center in Boulder, Colorado (http://www.cdc.noaa.gov/). To determine the sea/land breeze system at Ratnagiri during the study period, simultaneous wind measurements were carried out using an Autonomous Weather Station (AWS) at every $10 \mathrm{~min}$ interval. The AWS measures the wind speed in the range $0-60 \mathrm{~m} \mathrm{~s}^{-1}$ with an accuracy of $0.2 \mathrm{~m} \mathrm{~s}^{-1}$ and direction from 0 to $360^{\circ}$ with an accuracy of $3^{\circ}$.

Inverse wave age is the ratio of sea surface wind speed to the speed of the waves at the peak of the spectrum and is equal to $U_{10} \cos \theta / C_{\mathrm{p}}$ (Hanley et al., 2010). Here, $U_{10}$ is the $10 \mathrm{~m}$ wind speed, $\theta$ is the relative angle between the wind and the wave, and $C_{\mathrm{p}}$ is the peak phase speed $\left(C_{\mathrm{p}}=\mathrm{g} T_{\mathrm{p}} / 2 \pi\right)$. Inverse wave age is calculated using the measured wave data and the NCEP wind data. Three types of wind-wave interaction regimes, as in Hanley et al. (2010), are (i) wind driven wave regime when inverse wave age $>0.83$ (strong winds transfer momentum to waves), (ii) wave driven wind regime when inverse wave age $<0.15$ (fast moving swells transfer momentum towards near surface winds), and (iii) mixed wind wave regime when $0.15<$ inverse wave age $<0.83$ (both wind driven wave and wave driven wind are present).

\section{Results and discussion}

\subsection{Sea breeze and land breeze}

Two important parameters that characterize the waves are mean wave period and significant wave height. We used these two parameters to study the variation in wave characteristics (Figs. 2 and 3) at the study location along with wind direction and wind speed (Fig. 4) measured using an autonomous weather station. Neetu et al. (2006) reported the presence of a sea breeze system and its impact on the measured wave height during the premonsoon season. Their study using $3 \mathrm{~h}$ wave data shows the maximum wave height at 12:30 UTC and also observed the presence of land breeze during the early hours of the day.

The present study shows the presence of a sea/land breeze system with reversal of wind direction and simultaneous changes in wind speed over the diurnal cycle (Fig. 4) during pre- and postmonsoon seasons. Observed sea breeze shows a maximum during the premonsoon. Maximum wind speed on a daily basis occurs at 09:30 UTC during premonsoon and at 12:30 UTC during postmonsoon seasons. The observed direction of the sea breeze is from the NW and that of the land breeze is NE. Wind speed measured using an autonomous weather station shows that sea breeze during pre- and postmonsoon season varies between $1-3 \mathrm{~m} \mathrm{~s}^{-1}$, whereas land breeze strength is always less than $1 \mathrm{~m} \mathrm{~s}^{-1}$. During the $\mathrm{SW}$ monsoon season, wind strength is between 1 and $4 \mathrm{~m} \mathrm{~s}^{-1}$ throughout the day. The low values of wind speed observed, compared to Kumar et al. (2006), are due to the reduction in wind speed from ocean to land. The location of the AWS is on land in the coastal region of Ratnagiri, whereas the values reported by Kumar et al. (2006) are based on NCEP wind for an ocean location. Analysis shows that during the preand postmonsoon periods, wave height reaches a maximum value at around 15:00 UTC, similar to the observations of Pattiaratchi et al. (1997) and Pokheral and Lee (2011) because of the sea breeze persisting over the coastal region of India and resulting wind sea. Minimum wave height is observed during the early hours of the day (03:00-06:00 UTC) due to the land breeze system. The presence of longer period swells over the region is high during the strong land breeze period between 06:00-09:00 UTC (Fig. 3) and resulted in the maximum value during the mean wave period. The hourly average of the mean wave period indicates the co-occurrence of maximum sea breeze and decrease in the mean wave period between 09:30 UTC and 12:30 UTC (Figs. 3 and 4) during pre- and postmonsoon seasons. The estimated time lag between the maximum wind speed and resultant maximum wave height is around 3-4 hours. Seasonal analysis shows a slight increase in time lag during the postmonsoon season compared with the premonsoon season due to the decrease in sea breeze strength (Fig. 4) during the postmonsoon season compared to the premonsoon season. The estimated difference in time lag between premonsoon and postmonsoon is 

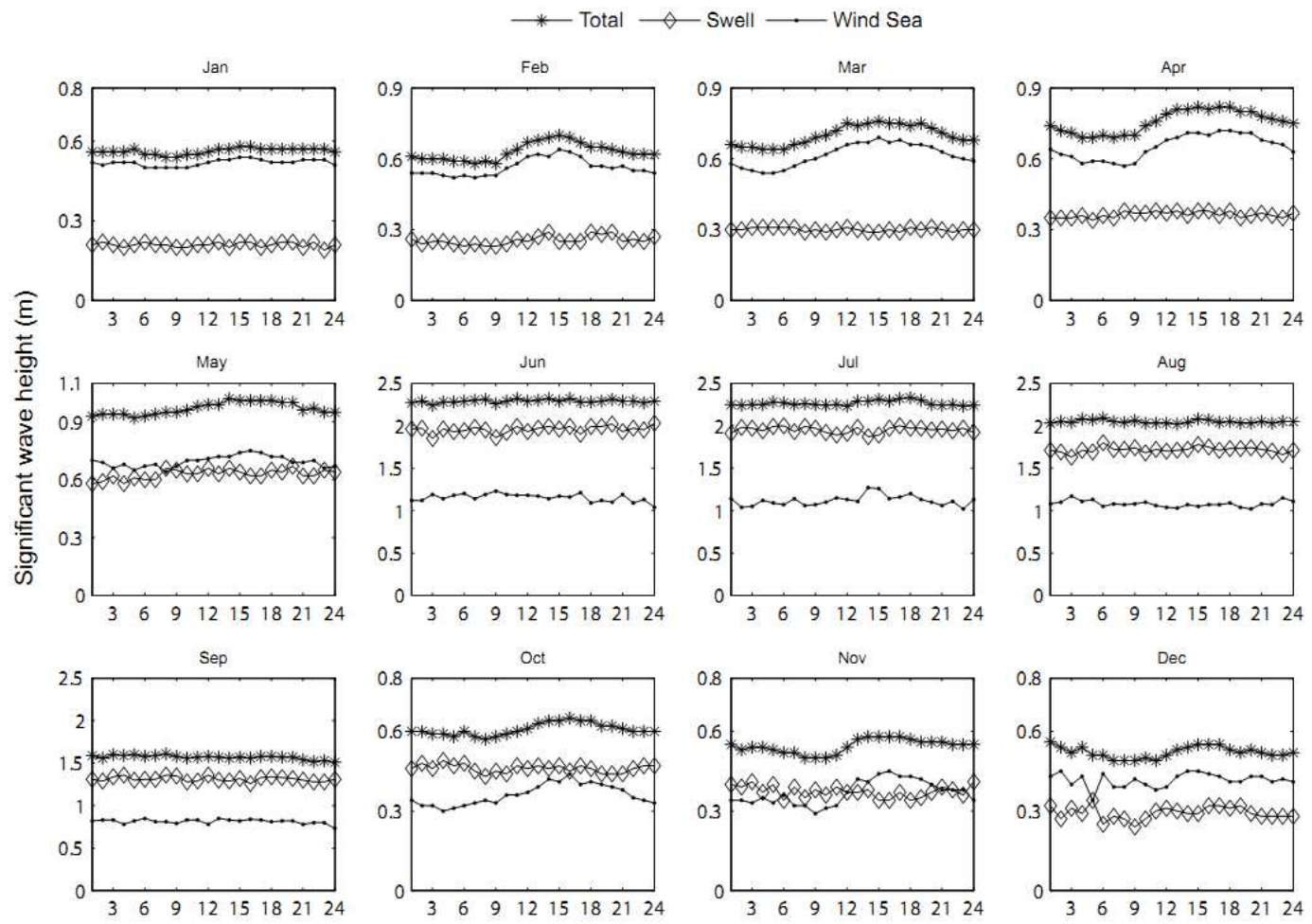

Time interval (hrs)

Fig. 2. Hourly variation of monthly average significant wave height during 2011, in UTC.
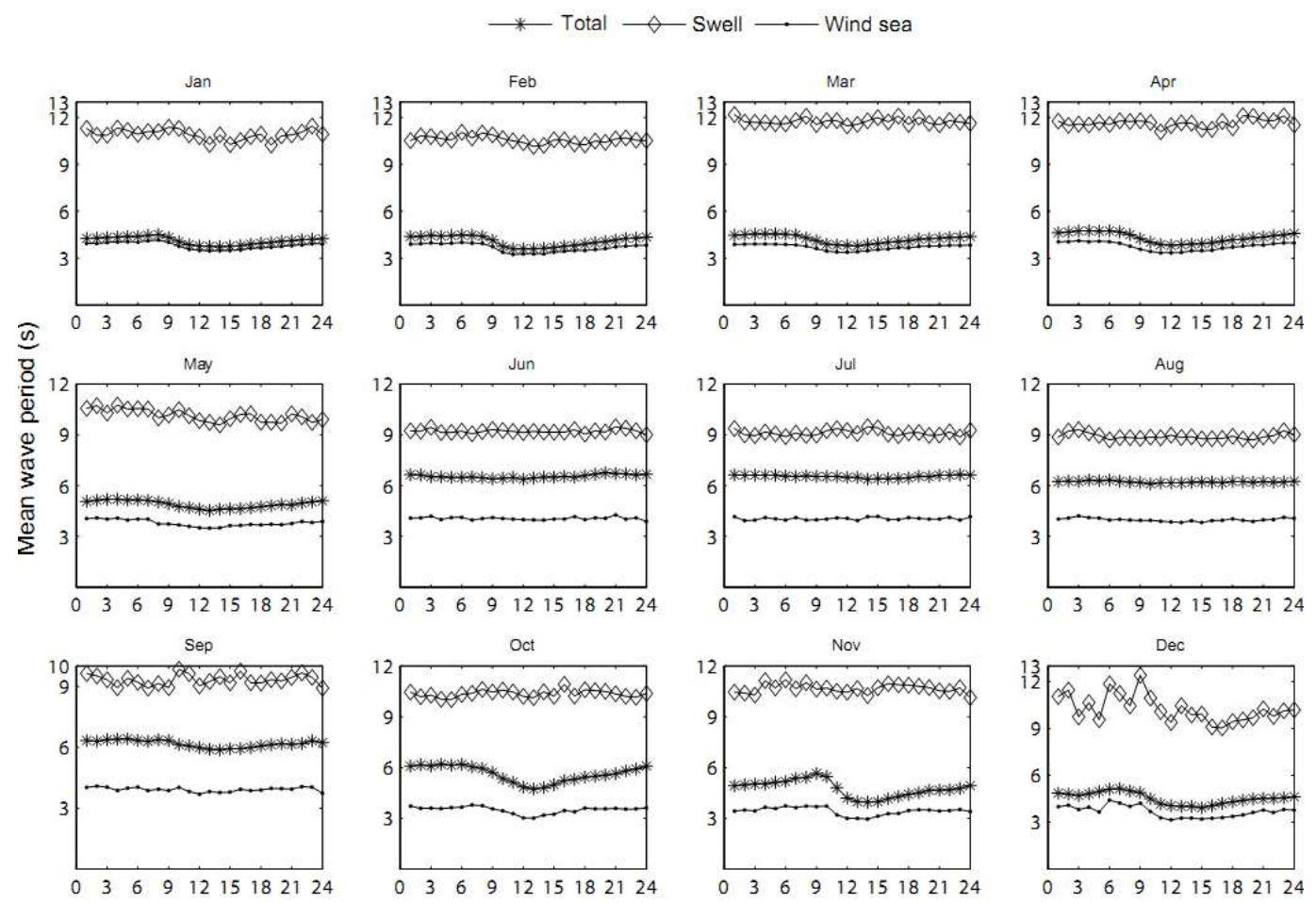

Time interval (hrs)

Fig. 3. Hourly variation of mean wave period $\left(T_{m 02}\right)$ during 2011 , in UTC. 


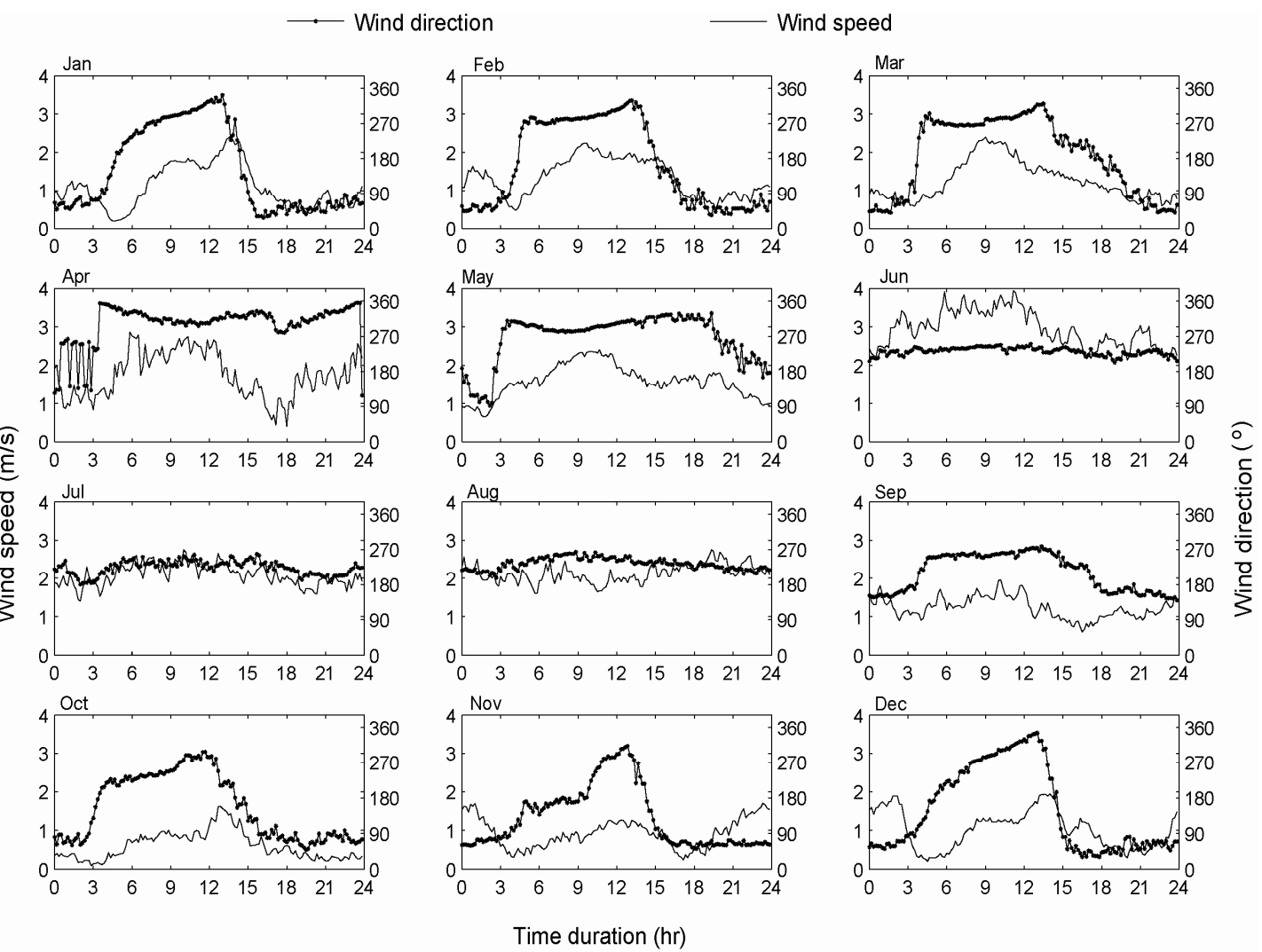

Fig. 4. Hourly variation of wind speed and wind direction during 2011, in UTC.

$1-2 \mathrm{~h}$. The time lag is due to the time taken by the waves to reach their maximum wave growth (Neetu et al., 2006). The mean wave period and significant wave height of measured waves depend on the combination of both swell and wind sea over the measurement location. The observed swells show a negligible hourly variation in wave height and wave period during the day since the swells are not influenced by the sea/land breeze. Near-shore wave climate during the sea breeze system is purely dependent on the short period waves (wind seas). The increase in significant wave height from January to May is caused by wind seas generated due to sea breezes (Fig. 2) and decreasing the trend from October to December is due to the corresponding variations in intensity of swells.

During the summer monsoon (June-September), the land and sea breezes are weak and the swells dominate the study area. The mean wave period and mean wave height are different from rest of the year and both are dependent on the strength of SW monsoon winds.

A calculation is made to estimate the average distance to the observation area from the wind sea generation area (due to sea breeze) during the premonsoon and postmonsoon seasons. The distance travelled by the waves to reach the observation area is calculated using the time difference between the minimum and maximum value of mean wave period and the group velocity estimated from mean wave period. The estimated distance of wave generation is around $40-50 \mathrm{~km}$ from the measurement location and is closer than that estimated $(70-80 \mathrm{~km})$ by Vethamony et al. (2011) for the Goa region.

\subsection{Inverse Wave age and distant swells}

Figure 5 depicts the seasonal and annual distribution of inverse wave age during 2010 and 2011, and is used to identify the occurrences of wind driven waves and wave driven/modified wind regimes in the study area. The distribution of inverse wave age is almost identical in 2010 and 2011 on seasonal and annual scales. During the strong SW monsoon season, the dominance of swells with the presence of wind seas (mixed wind wave regime) (Fig. 5b) is observed with inverse wave age in the range of $0.3-0.5$ due to strong SW winds. Usually, positive wave age is associated with SW monsoonal waves with mixed wind wave regimes. The analysis of the inverse wave age in three seasons indicates that during 2010 and 2011 the inverse wave age is positive from the start of the SW monsoon season in June and continues with positive values till the end of the SW monsoon season (September). The small peak in the negative region of inverse wave age distribution indicates the early withdrawal of 

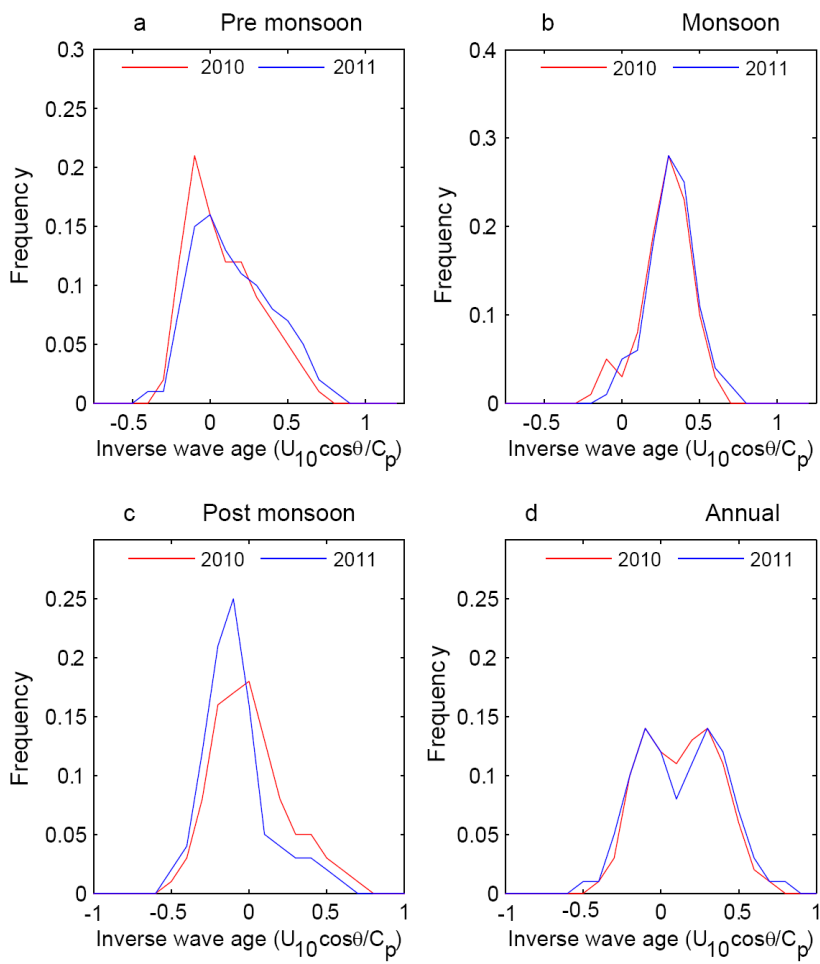

Fig. 5. Histogram of inverse wave age calculated based on observed wave direction and NCEP wind data at Ratnagiri during (a) premonsoon, (b) monsoon, (c) postmonsoon and, (d) annual 2010-2012.

summer monsoon winds reaching the central west coast of India in 2010 compared to 2011. Inverse wave age distribution in the postmonsoon period of 2010 indicates a typical example for the wind system in the study area without the occurrence of any storms and cyclonic activities in northern Indian Ocean.

Negative values of inverse wave age during the premonsoon season of 2010 and postmonsoon season of 2011 indicate the presence of storms and cyclonic activities over the Arabian Sea. During the pre- and postmonsoon period, the wind direction is NE (Fig. 6) and makes a relative wind wave angle of more than $90^{\circ}$ with waves from NW and SW direction. This induces a more frequent occurrence of inverse wave age in the range of -0.2 to 0 compared to the frequency distribution peak of 0.17 (Fig. 5) during the pre- and postmonsoon season without cyclones. This higher occurrence of smaller inverse wave age $(-0.2$ to 0$)$ of more than 0.17 during premonsoon of 2010 (Fig. 5a) and postmonsoon of 2011 (Fig. 5c) are observed with the presence of cyclonic activity over the Arabian Sea. During these seasons, the near shore region is dominated by inverse wave age values less than 0.2 with peak in the region of negative values (Hanley et al., 2010). This indicates a shift from mixed wind wave regimes during SW monsoon to wave modified wind regime during pre- and postmonsoon seasons, respectively. Negative Values of inverse wave age indicate the dominance of swells in the Arabian Sea propagating against the seasonal winds (Hanley et al., 2010), this contradicts the present study, which indicates the domination of wind sea due to sea/land breeze circulation over the eastern Arabian Sea (Table 1). This is due to the fact that large-scale winds show the seasonal wind pattern over the region without the local sea/land breeze circulation. In an annual period, the study region is characterized by the mixed and wave modified wind regime (Fig. 5d). Purely wind induced waves are negligible in the study area.

So we used a variant of inverse wave age equal to $U_{10} / C_{\mathrm{p}}$ to represent the sea state during pre- and postmonsoon seasons. The sea state is in the mixed sea state during all seasons with swell domination during the SW monsoon period (Table 2) and wind sea domination during pre- and postmonsoon periods (Table 1). Along the west coast of India, the offshore extent of sea breeze is $180 \mathrm{~km}$ (Aparna et al., 2005). The present study shows that the study of Hanley et al. (2010) based on inverse wave age considering the relative angle between wind and wave is only applicable to a region outside the sea breeze/land breeze circulation system. Hanley et al. (2010) have shown dominance of swells over the tropical Indian Ocean using the $40 \mathrm{yr}$ European Centre for MediumRange Weather Forecasts (ECMWF) data, which give similar results to our study with NCEP wind data.

\subsubsection{Southern Ocean swells}

The propagation of a swell generated in a Southern Ocean storm is identified in the northern Indian Ocean off Ratnagiri. These swells are identified by the increase in peak wave period and corresponding change in the swell period and swell height. The normal wave condition at Ratnagiri is with a peak swell period in the range of 8-12 $\mathrm{s}$ and these waves are result of a strong SW summer monsoon winds of $15 \mathrm{~m} \mathrm{~s}^{-1}$ (Kumar et al., 2006). During 7-8 August 2011 (period of the summer monsoon of 2011), waves having peak periods of 17-20 s were observed at Ratnagiri. To produce a wave with peak period of about $20 \mathrm{~s}\left(C_{\mathrm{p}} \sim 31 \mathrm{~m} \mathrm{~s}^{-1}\right)$, a minimum wind speed of $25 \mathrm{~m} \mathrm{~s}^{-1}\left(U=0.83 C_{\mathrm{p}}\right)$ is required and, mostly, these high wind speeds are a result of the Southern Ocean storms (Fig. 7). Figure 7 shows the movements of a Southern Ocean storm from west to east, with a SW wind direction blowing towards the Indian Ocean during 1-2 August 2011. The swell generated at the Southern Ocean propagates with a group speed of $14 \mathrm{~m} \mathrm{~s}^{-1}$ towards the Indian Ocean according to the winds over the region. The propagation time of 5-6 days is estimated for the swell to reach Ratnagiri across the Indian Ocean. The direction of propagation for these long period swells are from the SW direction of $240^{\circ}$ with mean significant swell height of $2.5 \mathrm{~m}$.

\subsection{Classification of waves}

For the proper understanding of seasonal and annual wave climate in the Arabian Sea off Ratnagiri, waves are classified 
Table 1. Seasonal percentages of wind sea and swell conditions in 2010 and 2011.

\begin{tabular}{|c|c|c|c|c|c|c|c|c|c|}
\hline \multirow[b]{2}{*}{ Season } & \multirow[b]{2}{*}{ Period } & \multicolumn{4}{|c|}{ Swell } & \multicolumn{4}{|c|}{ Wind sea } \\
\hline & & Percentage & $\begin{array}{l}\text { Height } \\
\text { (m) }\end{array}$ & $\begin{array}{l}\text { Period } \\
\text { (s) }\end{array}$ & $\begin{array}{l}\text { Direction } \\
\quad\left({ }^{\circ}\right)\end{array}$ & Percentage & $\begin{array}{l}\text { Height } \\
\text { (m) }\end{array}$ & $\begin{array}{l}\text { Period } \\
\text { (s) }\end{array}$ & $\begin{array}{c}\text { Direction } \\
\left({ }^{\circ}\right)\end{array}$ \\
\hline Premonsoon & & 28 & 0.4 & 11 & 238 & 72 & 0.7 & 4 & 299 \\
\hline SW monsoon & 2010 & 74 & 1.7 & 9 & 256 & 26 & 0.9 & 4 & 260 \\
\hline Postmonsoon & & 33 & 0.3 & 11 & 236 & 67 & 0.5 & 4 & 296 \\
\hline Premonsoon & & 27 & 0.4 & 11 & 242 & 73 & 0.7 & 4 & 299 \\
\hline SW monsoon & 2011 & 72 & 1.7 & 9 & 258 & 28 & 1.0 & 4 & 260 \\
\hline Postmonsoon & & 40 & 0.4 & 11 & 237 & 60 & 0.5 & 4 & 299 \\
\hline
\end{tabular}

Table 2. Classification of sea state based on inverse wave age calculated using $U_{10} / C_{\mathrm{p}}$ and $U_{10} \cos \theta / C_{\mathrm{p}}$.

\begin{tabular}{|c|c|c|c|c|c|c|}
\hline \multirow[b]{2}{*}{ Season } & \multicolumn{3}{|c|}{ classification based on $U_{10} / C_{\mathrm{p}}$} & \multicolumn{3}{|c|}{ classification based on $U_{10} \cos \theta / C_{\mathrm{p}}$} \\
\hline & $\begin{array}{r}\text { Wind } \\
\text { driven wave } \\
(\%)\end{array}$ & $\begin{array}{r}\text { Mixed } \\
(\%)\end{array}$ & $\begin{array}{r}\text { Wave driven/ } \\
\text { modified wind } \\
(\%)\end{array}$ & $\begin{array}{r}\text { Wind } \\
\text { driven wave } \\
(\%)\end{array}$ & $\begin{array}{l}\text { Mixed } \\
(\%)\end{array}$ & $\begin{array}{r}\text { Wave driven/ } \\
\text { modified wind } \\
(\%)\end{array}$ \\
\hline Premonsoon & 2 & 75 & 23 & 1 & 46 & 53 \\
\hline SW monsoon & 0.2 & 92 & 7.8 & 0.5 & 89 & 10.5 \\
\hline Postmonsoon & 2 & 65 & 33 & 0.3 & 21.7 & 78 \\
\hline
\end{tabular}

into three categories based on the spectral peak period $\left(T_{\mathrm{p}}\right)$; (1) short period waves, (2) intermediate period waves and (3) long period waves.

\subsubsection{Short period waves}

Waves with short periods $\left(T_{\mathrm{p}}<8 \mathrm{~s}\right)$ are mainly observed during the pre- and postmonsoon season. This is due to the domination of wind seas produced by the local wind system of sea breezes (Pattiaratchi et al., 1997) and the Shamal swells (Aboobacker et al., 2011a) produced by the Shamal winds over the Persian Gulf. These short period waves are mainly from the NW direction in pre- and postmonsoon seasons. During the SW monsoon season the waves are coming from the WSW direction due to strong SW monsoon winds (Fig. 8a-c).

\subsubsection{Intermediate period waves}

Intermediate period waves (8-13s) are mainly observed during the SW monsoon period. These waves are mainly from the west-southwest direction (Fig. 8d-f) and their origin and propagation are influenced by the SW monsoonal winds (Fig. 6b) in the southern Arabian Sea. Waves in the intermediate period are also observed from the NW direction due to the strong summer Shamal swells (Glejin et al., 2013) from the Persian Gulf. Significant wave height associated with these waves reaches up to $4.2 \mathrm{~m}$ (Table 3 ). During the SW monsoon period, waves generated by the SW monsoonal winds over the Arabian Sea dominate the energy spectrum and shift the peak period $\left(T_{\mathrm{p}}\right)$ towards the intermediate range of 8-13 s. Intermediate period waves are observed with relatively a low percentage of occurrence during the pre- and postmonsoon seasons because of minimum wind speed over the Arabian Sea during these seasons (Fig. 6).

\subsubsection{Long period waves}

The presence of long period waves $\left(T_{\mathrm{p}}>1 \mathrm{~s}\right)$ is persistent throughout the year in the Arabian Sea (Fig. 8g-i). These long period waves are dominant during the pre- $(45 \%)$ and postmonsoon $(47 \%)$ seasons. These are a minimum $(8 \%)$ during the southwest monsoon season due to the dissipation of long period swells by the strong easterly winds over tropical south Indian Ocean during the strong SW monsoon. This type of swell dissipation in strong wind is reported earlier by Ardhuin and Jenkins (2005). The direction of propagation of long period waves is mainly restricted to the SW region, indicating the presence of waves from the south Indian Ocean and Southern ocean. The long period waves with periods over $18 \mathrm{~s}$ from the Southern Ocean are observed during all three seasons.

\subsection{Frequency-Time diagram}

The spectral energy and direction of wave propagation represents the near shore wave climate. Figure 9 depicts the seasonal variation of normalized wave spectral energy density and wave direction within a frequency-time diagram during different seasons. During the premonsoon period, a relatively 


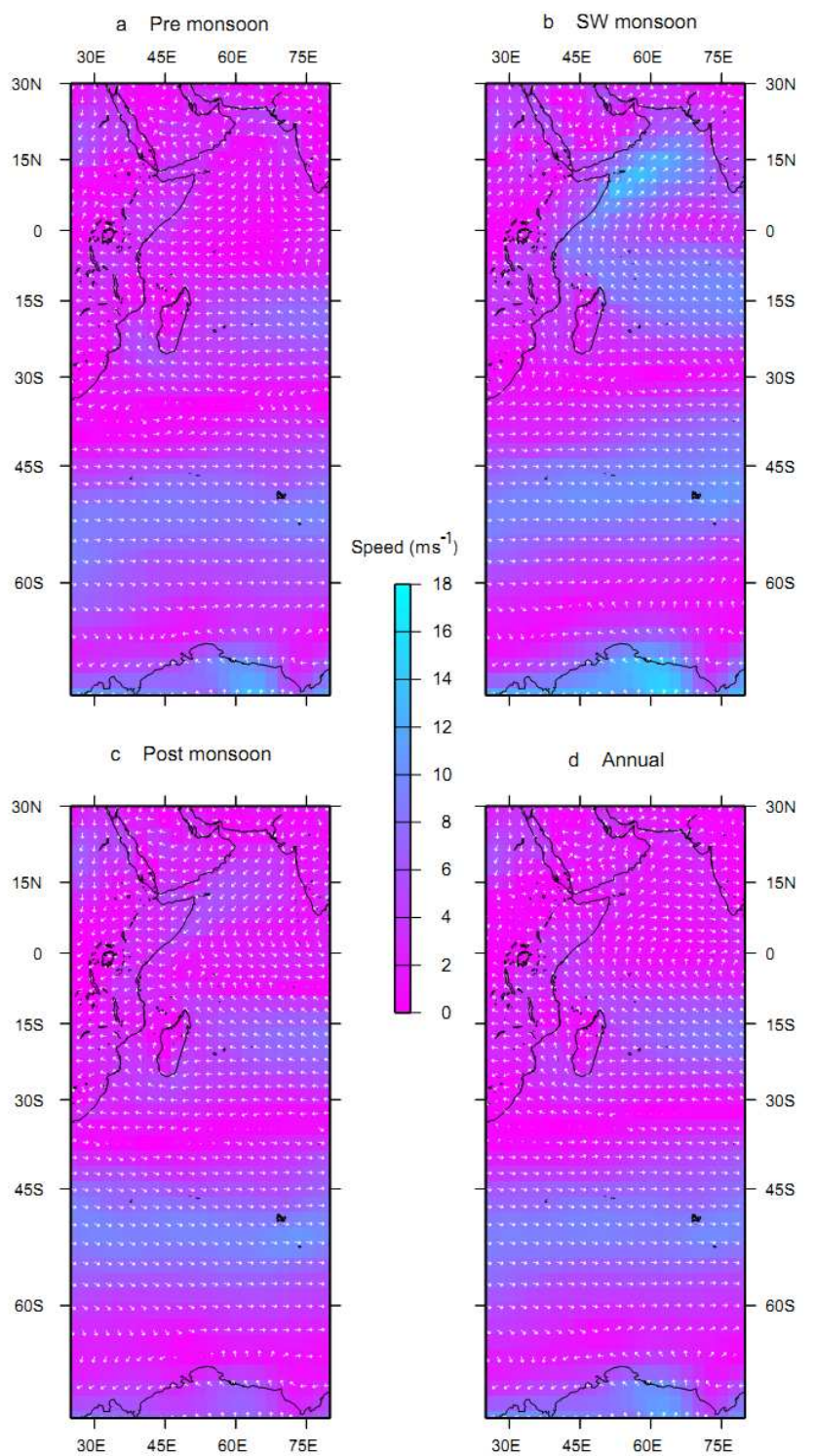

Fig. 6. Seasonal and annual composite image of NCEP wind over western Indian Ocean.

calm wind condition prevails over the southern Arabian Sea compared with the northern Arabian Sea because of the NW Shamal winds (Aboobacker et al., 2011a). The dominant sea breeze system results in the concentration of wave energy near 0.2 and $0.1 \mathrm{~Hz}$ (Fig. 9a-b). The wave energy is shifting towards the lower frequency region due to the strengthening of SW monsoon winds over the southern Arabian Sea and the Indian Ocean. The presence of SW swells propagated from the Southern Ocean with a peak period of more than $15 \mathrm{~s}$ dominates in 2011 during 15-18 May and indicates two separate bands of energy in the Arabian Sea.

The SW monsoon season is dominated by the swells and wind seas produced by the monsoonal winds reaching the near shore area from the SW direction. The NW swells and

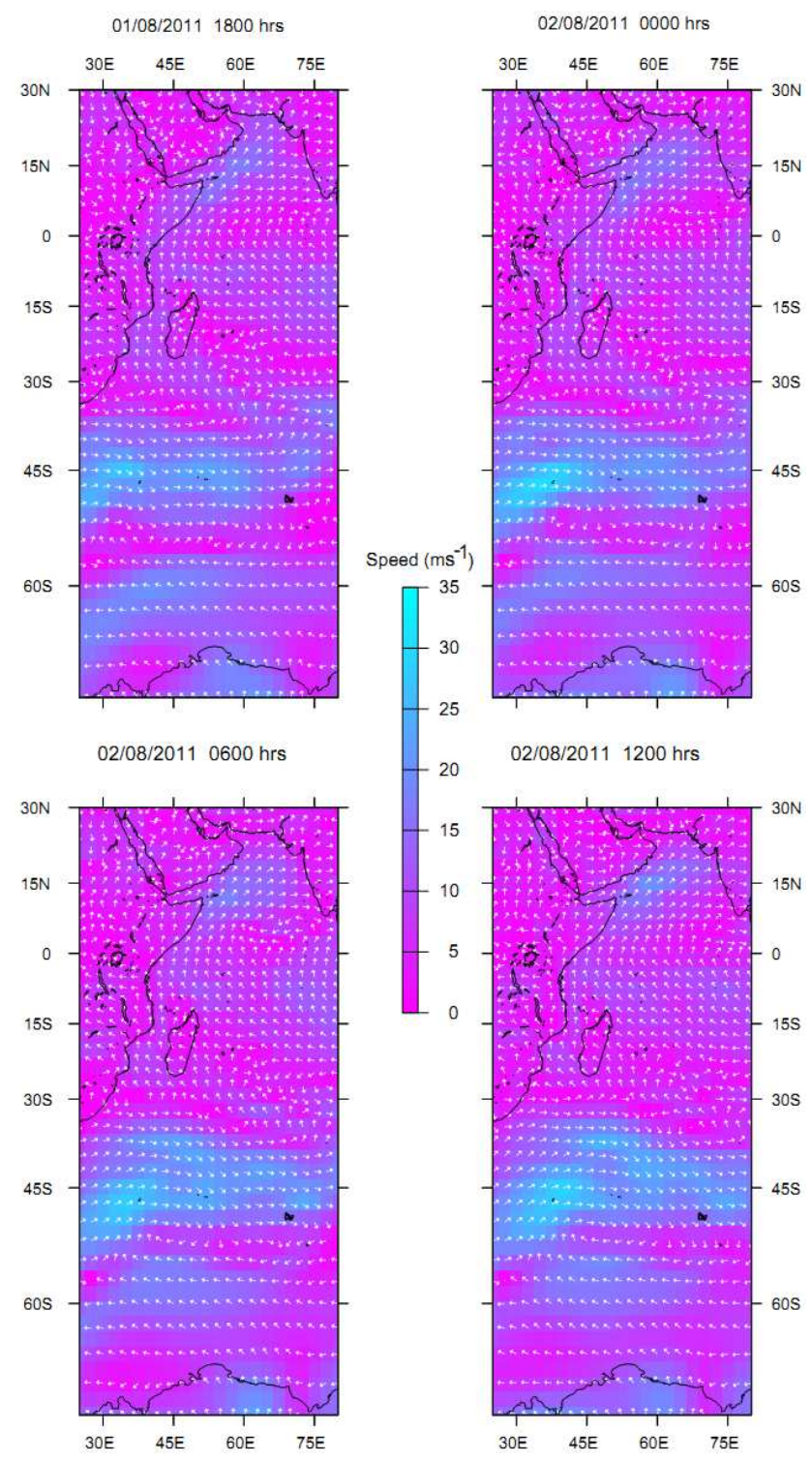

Fig. 7. Southern Ocean and Indian Ocean wind systems during 1 and 2 August showing the propagation of the storm from west to east.

wind seas due to summer Shamal (Glejin et al., 2013) winds are also observed during the SW monsoon season of 2010 and 2011. The energy spectra during the SW monsoon season are concentrated to a single band with period ranging from 8-13 s (Fig. 9c-d).

During the postmonsoon period, the wave energy is mainly concentrated in the frequency range of 0.1 and $0.3 \mathrm{~Hz}$ due to the NW swells and wind seas observed along the study area. During this period, the wave energy spectrum is characterized by the shifting of wave energy towards the higher frequency region (Fig. 9e-f). Weakening of SW monsoon generated swells and generation of short period waves as part of the sea breeze/land breeze system prevailing over the region 
Table 3. Monthly variation of sea state variables in 2011 .

\begin{tabular}{|c|c|c|c|c|c|c|c|c|c|c|c|c|}
\hline \multirow[b]{3}{*}{ Month } & \multicolumn{12}{|c|}{ Wave parameters } \\
\hline & \multicolumn{3}{|c|}{$\begin{array}{l}\text { Wave direction } \\
\left({ }^{\circ}\right)\end{array}$} & \multicolumn{3}{|c|}{$\begin{array}{l}\text { Sig. wave height } \\
\text { (m) }\end{array}$} & \multicolumn{3}{|c|}{$\begin{array}{c}\text { Maximum wave } \\
\text { height }(\mathrm{m})\end{array}$} & \multicolumn{3}{|c|}{$\begin{array}{c}\text { Mean wave perioc } \\
\text { (s) }\end{array}$} \\
\hline & $\min$ & $\max$ & avg & $\min$ & $\max$ & avg & $\min$ & $\max$ & avg & $\min$ & $\max$ & avg \\
\hline January & 208 & 333 & 292 & 0.3 & 1.1 & 0.6 & 0.4 & 2.0 & 0.9 & 2.9 & 5.5 & 4.1 \\
\hline February & 204 & 331 & 279 & 0.3 & 1.8 & 0.6 & 0.4 & 3.0 & 1.0 & 2.8 & 6.1 & 4.1 \\
\hline March & 197 & 325 & 278 & 0.4 & 1.2 & 0.7 & 0.5 & 2.3 & 1.1 & 3.0 & 7.9 & 4.2 \\
\hline April & 200 & 319 & 266 & 0.4 & 1.3 & 0.8 & 0.5 & 2.4 & 1.1 & 3.1 & 6.6 & 4.3 \\
\hline May & 204 & 314 & 260 & 0.7 & 1.7 & 1.0 & 0.9 & 3.0 & 1.5 & 3.6 & 6.7 & 4.9 \\
\hline June & 245 & 287 & 261 & 1.1 & 3.2 & 2.3 & 1.6 & 6.9 & 3.5 & 5.2 & 8.2 & 6.6 \\
\hline July & 232 & 274 & 259 & 1.4 & 4.0 & 2.3 & 2.0 & 7.0 & 3.5 & 4.9 & 8.0 & 6.5 \\
\hline August & 233 & 276 & 260 & 1.3 & 3.1 & 2.0 & 1.7 & 5.5 & 3.2 & 5.0 & 7.7 & 6.2 \\
\hline September & 218 & 276 & 252 & 0.6 & 4.2 & 1.6 & 0.8 & 6.5 & 2.4 & 4.0 & 7.9 & 6.2 \\
\hline October & 204 & 322 & 241 & 0.3 & 1.0 & 0.6 & 0.4 & 1.7 & 0.9 & 2.9 & 10.2 & 5.6 \\
\hline November & 203 & 335 & 241 & 0.2 & 1.3 & 0.5 & 0.4 & 2.4 & 0.8 & 2.9 & 7.8 & 4.8 \\
\hline December & 217 & 322 & 258 & 0.4 & 0.9 & 0.5 & 0.5 & 1.6 & 0.8 & 3.4 & 6.2 & 4.5 \\
\hline
\end{tabular}

$\min -$ Minimum

max - Maximum

avg - Average

results in a shift of energy towards higher frequency. The waves having periods between 12 and $22 \mathrm{~s}$ are only due to the SW swells.

\subsection{Wind sea and swell domination}

Analysis of wind sea and swell is a useful way to assess the influence of wind on near shore wave characteristics. Wave data of 2010 and 2011 are used to analyze the dominating type of wave (Table 1). The relative magnitudes of the wind seas and swells during the pre- and SW-monsoon season are almost identical during 2010 and 2011. The domination of swells is observed during the SW monsoon season (74 and $72 \%$ during 2010 and 2011) and wind seas are observed during the premonsoon season (72 and $73 \%$ during 2010 and 2011 respectively). During the postmonsoon period, the wind seas are $67 \%$ in 2010 and $60 \%$ in 2011. Aboobacker et al. (2011b) reported the dominance of swells during the postmonsoon season of 1997. The presence of higher cyclonic activity during the year 2011 compared to 2010 (Indian meteorological department: IMD, 2011, 2012) influenced the presence of swells and wind seas along the study region. This caused the arrival of more swells at the wave measurement area, with an increase of $7 \%$ of swells during the postmonsoon period in 2011 compared with 2010.

The mean period of wind seas is $4 \mathrm{~s}$ and shows similar characteristics in wind seas direction during pre- and postmonsoon periods. The dominant swells reaching the central west coast of India are from the SW direction and the corresponding wind seas are from the NW direction except during the SW monsoon period. Wind sea direction during the SW monsoon is $260^{\circ}$ because of a strong SW monsoonal
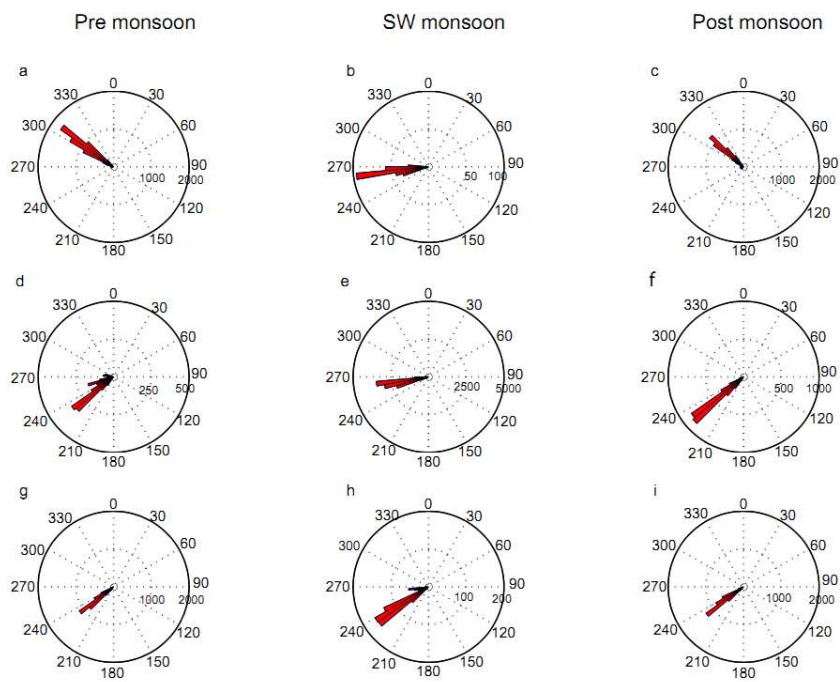

Fig. 8. Seasonal variations in wave direction of short period waves during (a) premonsoon, (b) monsoon and (c) postmonsoon, intermediate period waves during (d) premonsoon (e) monsoon and (f) postmonsoon, long period waves during (g) premonsoon (h) monsoon and (i) postmonsoon. X-axis to right or left from the center indicates the number of values in each band.

wind pattern and, therefore, produces the wind seas from the WSW direction. Maximum swell period and minimum swell height is observed during the pre- and postmonsoon seasons. Additionally, during the SW monsoon period, the swell wave height is at an annual maximum, due to strong SW monsoon winds, and swell period is at a minimum. 

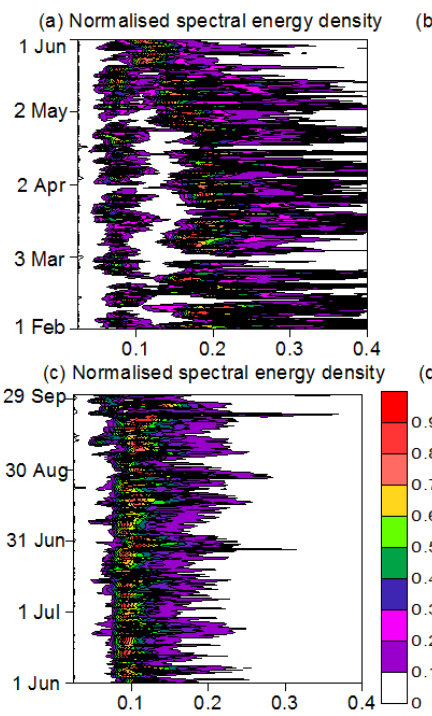

(e) Normalised spectral energy density

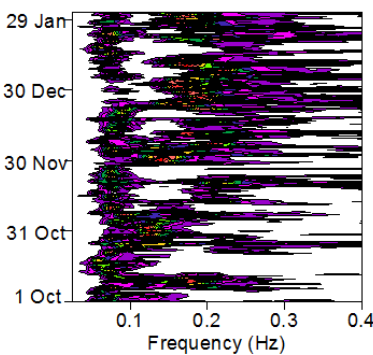

(b) wave direction during pre-monsoon

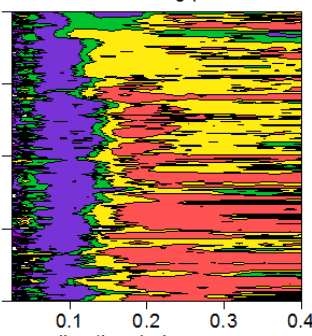

$\begin{array}{llll}0.1 & 0.2 & 0.3 & 0.4\end{array}$

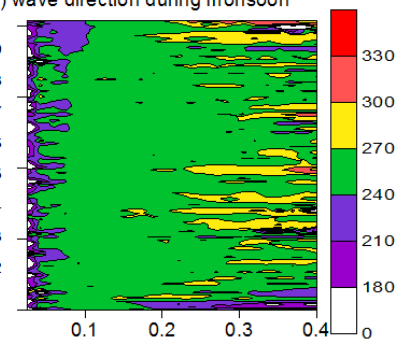

(f) wave direction during post-monsoon

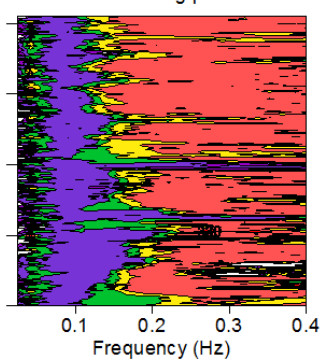

Fig. 9. Normalised spectral energy density and mean wave direction during premonsoon $(\mathbf{a}, \mathbf{b})$, monsoon $(\mathbf{c}, \mathbf{d})$ and postmonsoon $(\mathbf{e}, \mathbf{f})$ periods.

\subsection{Sea state and wave characteristics}

Wave data collected during 2011 is used to analyze monthly, seasonal and annual wave characteristics of near shore waves. Significant wave height varied between a minimum of 0.2 and a maximum of $4.2 \mathrm{~m}$ during the year 2011 (Table 3 ). Kumar et al. (2006) reported significant wave height up to $6 \mathrm{~m}$ during the summer monsoon period off the west coast of India during the cyclone period. Significant wave heights up to $4.3 \mathrm{~m}$ were observed during the summer monsoon of 2009 at a location $350 \mathrm{~km}$ south of the present study area (Sajiv et al., 2012) and is similar to the maximum value observed in the study region during 2011. During the premonsoon and postmonsoon seasons, sea state varies from smooth to moderate state. Sea state is in its extreme condition with maximum wave height up to $7 \mathrm{~m}$ (Table 3) from June to September (SW monsoon) due to high winds of the SW monsoon. Significant wave heights are at maximum during the SW monsoon season and at minimum during the postmonsoon season; values in the premonsoon season are intermediate. The increase in wave height in the premonsoon season is due to the presence of the sea breeze system during the period. Peak wave direction varied from 197 to $335^{\circ}$ with an average value of $262^{\circ}$

and the variation between lower and upper limit of wave direction is maximum in the pre- and postmonsoon season and minimum during the SW summer monsoon.

\section{Conclusions}

Wave data collected off Ratnagiri for the years 2010 and 2011 are used to analyze the effect of wind systems on the near shore waves observed off the central west coast of India. The presence of waves from the NW are due to the wind seas produced by the sea breeze and short period swells by the Shamal events. During the premonsoon and postmonsoon periods, the near shore wave characteristics are induced by the sea breeze blowing over the region and wave heights reach maximum values at around 15:00 UTC. Swells propagated from the Southern Ocean during an event in 2011 are identified with a travelling time of 5-6 days to reach the west coast of India during the SW monsoon period with an unique direction of $240^{\circ}$. Long period waves are also observed with low wave height mainly during the pre- and postmonsoon season and these waves are always restricted to the SW direction. In the near shore waters of the eastern Arabian Sea, where sea/land breeze systems persist, the sea state is characterized by inverse wave age indicating a mixed state for $77 \%$, wave modified wind for $21 \%$ and wind driven wave for $2 \%$ of the time during an annual cycle. The wind sea domination is observed during the calm premonsoon season and swell domination during the rough SW monsoon season. The variation in the presence of swells and wind seas during the postmonsoon season depends upon the cyclonic activity occurring in the Arabian Sea.

Acknowledgements. Indian National Centre for Ocean Information System (Ministry of Earth Sciences), Hyderabad funded the measurement. The authors thank the director of CSIR-NIO and the director of INCOIS for providing facilities and encouragement. We also thank Arun Nherakkol and Late K. Ashok Kumar for the help during the wave data collection and Prakash Mehra for providing the AWS data. We thank the topic editor and reviewers for critical comments and suggestions. This work forms part of the Ph.D. thesis of the first author. This paper is NIO contribution number 5238 and INCOIS contribution number 139.

Edited by: J. M. Huthnance

\section{References}

Aboobacker, V. M., Vethamony P., and Rashmi R.: "Shamal" swells in the Arabian Sea and their influence along the west coast of India, Geophys.Res. Lett., 38, 1-7, 2011a.

Aboobacker, V. M., Rashmi, R., Vethamony, P., and Menon, H. B.: On the dominance of pre-existing swells over wind seas along the west coast of India, Cont. Shelf. Res., 31, 1701-1712, $2011 \mathrm{~b}$.

Aparna, M., Shetye, S. R., Shankar, D., Shenoi, S. S. C., Mehra, P., and Desai, R. G. P.: Estimating the seaward extent of sea breeze 
from QuikSCAT scatterometry, Geophys. Res. Lett., 32, L13601, doi:10.1029/2005GL023107, 2005.

Ardhuin, F. and Jenkins, A. D.: On the effect of wind and turbulence on ocean swell. Proc. 15th Int. Polar and Offshore Engineering Conf., Vol. III, Seoul, South Korea, ISOPE, 429-434, 2005.

Ardhuin, F. and Jenkins, A. D.: On the Interaction of Surface Waves and Upper Ocean Turbulence, J. Phys. Oceanogr., 36, 551-557, 2006.

Ardhuin, F., Chapron, B., and Collard, F.: Observation of swell dissipation across oceans, J. Geophys. Res., 6, 1-5, 2009.

Barber, N. F. and Ursell, F.: The generation and propagation of ocean waves and swell, I. Wave periods and velocities, Philos. Trans. Roy. Soc. A, 240, 527-560, 1948.

Barstow, S. F. and Kollstad, T.: Field trials of the directional wave rider, Proceedings of the First International Offshore and Polar Engineering Conference, Edinburgh, III, 55-63, 1991.

Donelan, M., Hamilton, H., and Hui, W. H.: Directional spectra of wind-generated waves, Phil. Trans. R. Soc. Lond. A, 315, 509$562,1985$.

Glejin, J, Kumar, V. S., Chempalayil, S. P., Singh, J., Pednekar, P., Ashok, Kumar K., Udhaba Dora, G., and Gowthaman, R.: Variations in swells along eastern Arabian Sea during the summer monsoon, Open J. Mar. Sci., 2, 43-50, 2012.

Glejin, J., Kumar, V. S., Nair, T. M. B., Singh, J., and Mehra, P.: Observational evidence of summer Shamal swells along the west coast of India, J. Atmos. Oceanic. Technol., 30, 379-388, doi:10.1175/JTECH-D-12-00059.1, 2013.

Hamilton, D. G.: Measurement of long period ,Low Amplitude swell in the western north Atlantic ocean, J. Atmos. Oceanic. Technol., 9, 645-658, 1992.

Hanley, E. K, Stephen, E. B., and Peter, P. S.: A global Climatology of wind wave Interaction, J. Phys. Oceanogr., 40, 1263-1282, 2010.

Harris, D. L.: Wave driven Wind, J. Atmos. Sci., 23, 688-693, 1966.

Hristov, T. S., Miller, S. D., and Friehe, C. A.: Dynamical coupling of wind and ocean waves through wave-induced air snow, Nature, 422, 55-58, 2003.

Hwang, P. A., Garcia-Nava, H., Ocampo-Torres, F. J.: Dimensionally Consistent Similarity Relation of Ocean Surface Friction Coefficient in Mixed Seas, J. Phys. Oceanogr., 41, 1227-1238, 2011.

Indian meteorological department (IMD): RSMC- Tropical Cyclone Report No. 1/2011, January 2011.

India meteorological department (IMD): Report on cyclonic disturbances over North Indian Icean during 2011, RSMC- Tropical Cyclone Report No. 2/2012, January 2012.

Kalnay, E., Kanamitsu, M., Kistler, R., Collins, W., Deaven, D.,Gandin, L., Iredell, M., Saha, S., White, G., Woollen, J., Zhu, Y.,Chelliah, M., Ebisuzaki, W., Higgins, W., Janowiak, J., Mo, K., Ropelewski, C., Wang, J., Leetmaa, A., Reynolds, R., Jenne, R., and Joseph, D.: The NCEP/NCAR reanalysis project, B. Am. Meteorol. Soc., 77, 437-471, 1996.

Kuik, A. J., Vledder, G., and Holthuijsen, L. H.: A method for the routine analysis of pitch and roll buoy wave data, J. Phys. Oceanogr., 18, 1020-1034, 1988.
Kumar, V. S., Ashok Kumar, K., and Anand, N. M.: Characteristics of waves off Goa, west coast of India, J. Coastal Res., 16, 782789, 2000.

Kumar, V. S., Pathak, K. C., Pednekar, P., and Gowthaman, R.: Coastal processes along the Indian coastline, Current Sci., 91, 530-536, 2006.

Kumar, R., Bhowmick, S. A., Ray, S., Bhatt, V., Surendran, S. Basu, S., Sarkar, A., and Agarwal, V. K.: Improvement in predictability of waves over the Indian Ocean, Nat. Hazards, 49, 275-291, 2009.

Kumar, V. S., Glejin, J., Dora, G. U., Sajiv, P. C., Singh, J., and Pednekar, P.: Variations in nearshore waves along Karnataka, west coast of India, J. Earth Syst. Sci., 121, 393-403, 2012.

Kurian, N. P., Rajith, K., Shahul Hameed, T. S., Sheela Nair, L., Ramana Murthy, M. V., Arjun, S., and Shamji, V. R.: Wind waves and sediment transport regime off the south-central Kerala coast, India. Nat. Hazards, 49, 325-345, 2009.

Munk, W. H., Miller, G. R., Snodgrass, F. E., and Barber, N. F.: Directional recording of swell from distant storms, P. Trans. Roy. Soc. Lond., 255, 505-584, 1963.

Neetu, S., Shetye, S., and Chandramohan, P.: Impact of sea breeze on wind-seas off Goa, west coast of India, J. Earth Sys. Sci.,1 15, 2031-2038, 2006

Pattiaratchi, C., Hegge, B., Gould, J., and Eliot, I.: Impact of sea breeze activity on nearshore and foreshore processes in southern Australia, Cont. Shelf Res., 17, 1539-1560, 1997.

Pierson, W. J. and Moskowitz, L.: A proposed spectral form for fully developed wind seas based on the similarity theory of A. A. Kitaigoirodskii, J. Geophys. Res., 69, 5181-5190, 1964.

Pokheral, R. and Lee, H.: Estimation of the effective zone of sea/ Land breeze in a coastal area, Atmos. Pollut. Res., 2, 106-115, 2011.

Portilla, J., Ocampo-Torres, F. J., and Monbaliu, J.: Spectral Partitioning and Identification of Wind Sea and Swell, J. Atmos. Ocean. Technol., 26, 117-122, 2009.

Rao, C. V. K. P. and Baba, M.: Observed wave characteristics during growth and decay: a case study, Cont. Shelf Res., 16, 1509-1520, 1996.

Sajiv, P. C, Kumar, V. S., Glejin, J., Dora, G. U., and Vinayaraj, P.: Interannual and seasonal variations in near shore wave characteristics off Honnavar, west coast of India, Current Sci., 103 , 286-292, 2012.

Sanil Kumar, V., Sajiv Philip, C., and Balakrishnan Nair, T. N.: Waves in shallow water off west coast of India during the onset of summer monsoon, Ann. Geophys., 28, 817-824, doi:10.5194/angeo-28-817-2010, 2010.

Snodgrass, F. E., Groves G. W., Hasselmann K., Miller G. R., Munk W. H., and Powers W. H.: Propagation of ocean swells across the Pacific, Phil. Trans. Roy. Soc. A, 249, 431-497, 1966.

Vethamony, P., Aboobacker, V. M., Menon, H. B., Ashok Kumar, K., and Cavaleri, L.: Superposition of wind seas on the preexisting swells off Goa coast, J. Mar. Syst., 87, 47-54, 2011. 